\title{
Thomas Jefferson w peregrynacjach po Europie. Kilka uwag o Niderlandach drugiej polowy XVIII wieku
}

Thomas Jefferson (1743-1826) był postacia niezwykłą w swoich czasach i byłby zapewne taki i w czasach obecnych. Był nie tylko politykiem i mężem stanu, ale także $z$ powodzeniem uprawiał inne zawody. Interesował się wszystkim, a rozległość jego horyzontów myślowych zadziwia. Trudno jest jednym zdaniem określić jego dokonania. Był współautorem Deklaracji Niepodległości, dyplomata, prezydentem Stanów Zjednoczonych i założycielem Uniwersytetu Wirginii1. Zdaniem Zofii Libiszowskiej „wszystkie jego wypowiedzi, pisma, traktaty, rozważania i autobiograficzne zwierzenia były zawsze i niezmiennie wierne nadrzędnym zasadom, które chciał urzeczywistnić", a które można byłoby sprowadzić do trzech głównych idei - Demokracja, Naród, Oświecenie ${ }^{2}$.

Ważnym etapem w kształtowaniu poglądów Thomasa Jeffersona na świat były podróże. W roku 1784 dyplomata wyjechał do Europy, ponieważ otrzymał polecenie od Kongresu, aby wspomagać Benjamina Franklina (1706-1790) i Johna Adamsa (17351826) w zawieraniu układów handlowych $z$ różnymi państwami. Niespełna rok później, w marcu roku 1785 został mianowany ministrem pełnomocnym we Francji jako następca Benjamina Fran-

1 Postać Thomasa Jeffersona przybliżaja polskiemu czytelnikowi m.in. Z. Li b i s zow s k a, Tomasz Jefferson, Wrocław 1984; L. P a s tu siak, Anegdoty prezydenckie, t. I, Warszawa 2004, s. 47-64; id e m, Prezydenci od Georga'e Waszyngtona do George'a Busha, Warszawa 1991, s. 26-34; i d e m, Prezydenci Stanów Zjednoczonych Ameryki, wyd. II, Warszawa 1999, s. 76-99; W. Szys zk o w s ki, Twórcy Stanów Zjednoczonych: Waszyngton, Jefferson, Hamilton, Warszawa 1980.

2 Cyt. za: Z. Libis zow s ka, op. cit., s. 6. 
klina. Funkcję tę sprawował do października 1789 r. Podczas pobytu w Paryżu Thomas Jefferson odbył kilka podróży. Zwiedził część Anglii, Francję, północne Włochy, Niderlandy i zachodnie Niemcy. Doświadczenia płynace $z$ obcowania ze Starym Kontynentem i jego mieszkańcami utwierdziły go w przekonaniu, że przyszłość należy do Stanów Zjednoczonych, a nie do Europy³.

W artykule pragnę przedstawić opinie Thomasa Jeffersona na temat Niderlandów drugiej połowy wieku XVIII. Większość poglądów na temat tego regionu dyplomata sprecyzował właśnie podczas peregrynacji po Europie. Swoje spostrzeżenia zapisywał w dzienniku i w listach do przyjaciól, a po latach przypomniał także w Autobiografii. Poza tym w drodze prowadził księgę wydatków, a po powrocie napisał wskazówki dla Amerykanów pragnących odbyć podobną podró $\dot{z}^{4}$.

Niderlandy to historyczna nazwa nizinnych terenów u ujścia Renu, Mozy i Skaldy do Morza Północnego, z czasem rozciagnięta również na Ardeny i sąsiednie wyżyny. Sa to tereny dzisiejszej Belgii, Holandii i Luksemburga. Znaczna część tego obszaru położona jest poniżej poziomu morza. Dlatego od najdawniejszych czasów ludność budowała tu system wałów, tam i śluz chroniących przed zalewaniem. W wieku VIII n.e. zaczęto wydzierać morzu znaczne pola tworzac $z$ nich tzw. poldery, zdatne do zamieszkania i uprawy. Dzisiejsze ukształtowanie Niderlandów jest w dużej mierze rezultatem nie tylko działania sił przyrody, ale też wielowiekowej, uporczywej walki człowieka $z$ morzem.

W XVI stuleciu pod wpływem reformacji w północnych Niderlandach wybuchło powstanie, które przekształciło się w wojnę wyzwoleńcza spod panowania hiszpańskiego. W roku 1579 siedem prowincji (Holandia, Zelandia, Utrecht, Groningen, Fryzja, Overijssel

3 Podróże Thomasa Jeffersona sa tematem wielu prac. Por. m.in. B.F. Le B e a u, Thomas Jefferson, [w:] American Travel Writers, 1776-1864. Dictionary of Literary Biography, ed. J. Schramer, vol. CLXXXIII, Detroit-Washington D.C.-London 1997, s. 186-196; E. D u m b a u ld, Thomas Jefferson American Tourist. Being an Account of His Journeys in the United States of America, England, France, Italy, the Low Countries, and Germany, Norman 1946, s. 60-131; K. S t e 1 $\mathrm{m}$ a siak, Amerykanin $w$ Londynie. Królestwo Wielkiej Brytanii $w$ relacjach podróżniczych $z$ lat 1776-1796, Warszawa 2006.

${ }^{4}$ Bazę źródłową do napisania artykułu stanowiły m.in. The Autobiography of Thomas Jefferson, introd. by D. Malone, New York 1959; The Papers of Thomas Jefferson, ed. J.P. Boyd, vol. XII-XIII, Princeton 1955-1956; Thomas Jefferson's European Travel Diaries, ed. J. McGrath Morris, P. Weene, introd. by D.M. Sagar, New York 1987. 
i Geldria) podpisało unię utrechcka, sojusz skierowany przeciwko Hiszpanom, który okazał się pierwszym aktem na drodze do powstania nowego państwa. $\mathrm{W}$ tym samym roku południowe prowincje: Hainaut, Artois i Douai podpisały w Arras unię, katolickie porozumienie deklarujace lojalność wobec hiszpańskiego monarchy Filipa II (1527-1598). W ten sposób ustalił się podział Niderlandów na część południowa, zajmująca mniej więcej obszar dzisiejszej Belgii i Luksemburga, pozostajaca pod panowaniem hiszpańskim do roku $1713^{5}$ i część północną, która proklamowała w roku 1588 powstanie oddzielnego państwa - Republiki Zjednoczonych Prowincjí.

Od końca wieku XVI to nowe państwo przeżywało bujny rozkwit społeczny i gospodarczy. Do miast holenderskich przeniósł się handel zamorski, powstały nowe kompanie handlowe prowadzace wymianę towarową niemal $z$ całym ówczesnym światem. Republika brała także udział, razem $z$ Anglią i Francja, w kolonizacji Ameryki Północnej. W następnym stuleciu, nazywanym Złotym Wiekiem, Zjednoczone Prowincje należały do grona ekonomicznych potęg europejskich. Dominowały nie tylko w handlu i produkcji rzemieślniczej, ale również $\mathrm{w}$ dziedzinie protestanckiej kultury i sztuki .

Niestety w wieku XVIII kraj miał już za soba lata największego rozkwitu politycznego i kulturalnego. Pozycja międzynarodowa Republiki uległa znacznemu osłabieniu, a pokój w Utrechcie $z 1713 \mathrm{r}$. wiązał $\mathrm{w}$ istocie politykę niderlandzka $z$ angielska, pozbawiając ja samodzielności i dotychczasowego rozmachu. Nadal jednak był to ważny ośrodek myśli ludzkiej i dość prężne centrum handlowe.

Podczas wojny o niepodległość Stanów Zjednoczonych (17761783) Zjednoczone Prowincje utrzymywały neutralność $z$ powodu słabości swej armii i floty. Poza tym ogromny kapitał holenderski ulokowany za granica mógłby ulec konfiskacie w razie konfrontacji

5 W wyniku wojny o sukcesję hiszpańska (1702-1713) południowe Niderlandy w roku 1713 dostały się pod kontrolę cesarza Austrii i pozostawały w rękach austriackich do roku 1792 . Więcej na ten temat por. J. Ła p to s, Historia Belgii, Wrocław 1995, s. 96-99, 109-126.

6 O powstaniu Republiki Zjednoczonych Prowincji w końcu wieku XVI por. m.in. J. B a li c ki, M. B o g u c k a, Historia Holandii, Wrocław 1979, s. 107-143; J. Ła p to s, op. cit., s. 69-85; Z. W ój c i k, Historia powszechna XVI-XVII wiek, wyd. IV, Warszawa 1991, s. 263-295; A. Wy c zańs ki, Historia powszechna. Wiek XVI, wyd. II, Warszawa 1987, s. 204-209.

7 Więcej o Republice Zjednoczonych Prowincji w wieku XVII por. J. B a li c ki, M. B og u cka, op. cit., s. 147-213; A. Ke r s t e n, Historia powszechna. Wiek XVII, wyd. II, Warszawa 1987, s. 57-61; P. Z u m t h o r, Życie codzienne $w$ Holandii $w$ czasach Rembrandta, przekł. E. Bakowska, Warszawa 1965. 
zbrojnej. W kraju zarysowały się jednak poważne różnice poglądów pomiędzy namiestnikiem i patrycjatem na temat stosunku Republiki do zbuntowanych kolonii. Regenci, przede wszystkim amsterdamscy, widzieli otwierające się możliwości handlu $z$ Ameryka, który dotychczas zmonopolizowany był przez Anglię. Dlatego z należacych do Zjednoczonych Prowincji wysp Morza Karaibskiego płynęły szerokim strumieniem dostawy dla powstańców amerykańskich. Kupcy holenderscy handlowali materiałami wojennymi także $z$ Francją i Hiszpanią. W zaistniałej sytuacji rząd angielski uznał, że neutralność Republiki przynosi więcej szkody niż traktowanie jej jako nieprzyjaciela i dlatego w grudniu $1780 \mathrm{r}$. wypowiedział Holandii wojnę. Jej przebieg stanowił dla Zjednoczonych Prowincji pasmo klęsk. Sparaliżowana została żegluga, a na lądzie Holendrzy nie potrafili stawić czoła wojskom cesarza Józefa II (1741-1790), który jako władca południowych Niderlandów zażądał wycofania garnizonów Republiki $z$ pogranicza niderlandzkofrancuskiego i otwarcia ujścia Skaldy. Tym razem ponosząc klęski wojenne Zjednoczone Prowincje popadły w całkowita zależność od Francji. W kraju $z$ ulga powitano zawarcie pokoju w roku 1783, mimo że przynosił on pewne starty terytorialne w Indiach i dalszy spadek międzynarodowego znaczenia ${ }^{8}$.

Początkowo, pozostając $\mathrm{w}$ stanie wojny $\mathrm{z}$ Anglia, Zjednoczone Prowincje nie uznały niepodległości Stanów Zjednoczonych, chociaż, jak wspomniałam powyżej, udzielały znaczącej pomocy walczącym Amerykanom. Dlatego w grudniu 1780 r. Kongres postanowił wykorzystać sprzyjające okoliczności i wysłał z misją do Holandii przebywającego wówczas w Paryżu Johna Adamsa. Zrazu dyplomata przyjmowany był chłodno, ale dzięki zmieniającej się na korzyść Stanów Zjednoczonych sytuacji w wojnie $z$ Anglią oraz zręcznej działalności i poparciu ze strony Francji, w kwietniu 1782 r. Zjednoczone Prowincje uznały niepodległość Stanów Zjednoczonych. John Adams zdołał także wynegocjować układ handlowy i pożyczkę 9 .

W tym samym czasie zachodziły poważne przemiany społeczne i wydarzenia polityczne wewnatrz Republiki, które były zainspiro-

8 Por. J. Balicki, M. B ogucka, op. cit., s. 255-258; E. Ros tworows k i, Historia powszechna wiek XVIII, wyd. IV, Warszawa 1994, s. 532-533.

9 Por. L. P a s t u s i a k, Dyplomacja Stanów Zjednoczonych (XVIII-XIX w.), Torun-Warszawa 1997, s. 34-35. Więcej o wrażeniach Johna Adamsa z pobytu w Holandii por. J. Gro b is, Świat i polityka $w$ pogladach Johna i Johna Quincy Adamsów, Łódź 1989, s. 27-29, 99-104. 
wane ideałami oświecenia i rewolucji amerykańskiej. Na arenie politycznej pojawiła się nowa siła - patrioci, reprezentujący głównie średnich oraz drobnych posiadaczy i postulujący zasadnicze zmiany ustroju politycznego kraju. Ruch ten nie był jednolity wewnętrznie. Nurt arystokratyczny reprezentowany przez regentów domagał się przywrócenia „prawdziwej wolności”, czyli odzyskania władzy. Regenci atakowali namiestnika i pod hasłem „rządów ludu" rozumieli tradycyjne rządy Stanów Prowincjonalnych i Generalnych, które faktycznie były przez nich obsadzane. $Z$ kolei demokraci domagali się władzy, ale nie dla całego mieszczaństwa, a tylko dla zamożnych i wykształconych jego przedstawicieli.

Wkrótce w całym kraju zaczęły powstawać kluby i stowarzyszenia patriotów. Atakowano namiestnika Wilhelma V (1748-1806) za proangielska politykę, a potem obarczano go odpowiedzialnościa za niepowodzenia w wojnie $z$ Anglią. Krok po kroku odbierano mu poszczególne prerogatywy. Patrioci zorganizowali także własna siłę zbrojna typu milicyjnego i uzyskali dominujące wpływy w Stanach Generalnych i Prowincjonalnych.

Z kolei siły zachowawcze Republiki skupiły się wokół księcia i z pomoca ambasadora angielskiego zaczęły organizować partię orańska. Rozpoczęto ożywioną działalność propagandową, szczególnie wśród biedoty miejskiej. Powstały kluby oranżystowskie i oranżystwoskie oddziały ochotnicze, oparte na wzorach podpatrzonych u patriotów.

Patrioci postrzegani byli jako ruch profrancuski, podczas gdy oranżyści dążyli do osłabienia wpływów Francji. $Z$ czasem coraz więcej regentów odchodziło jednak od ruchu patriotycznego i sprzymierzało się $z$ namiestnikiem. Między oranżystami i patriotami dochodziło często do krwawych starć i aktów przemocy. Na szczęście do otwartej wojny domowej nie doszło, a władzę namiestnika uratowała interwencja pruska w roku 1787.

W jej wyniku Wilhelmowi V przywrócono wszystkie prerogatywy. Dziedziczność urzędu namiestnika uznana została za jedna $z$ konstytucyjnych zasad i umocniona gwarancja Anglii i Prus z 1788 r. Wkrótce wielu patriotów $\mathrm{w}$ obawie przed prześladowaniami udało się na emigrację, przeważnie do Francji ${ }^{10}$.

10 Obszerniej o ruchu patriotów i wydarzeniach $z$ lat osiemdziesiątych wieku XVIII w Republice Zjednoczonych Prowincji por. J. B a licki, M. B o g u cka, op. cit., s. 258-263; J. M a c i s z e w s k i, Historia powszechna. Wiek Oświecenia, wyd. II, Warszawa 1997, s. 115-116; E. R o s t w or ow s ki, op. cit., s. 577-579. 
W tym właśnie okresie Thomas Jefferson odbywał podróż po Niderlandach. Bezpośrednią przyczyną wyjazdu była chęć spotkania się $z$ Johnem Adamsem i wspólne wynegocjowanie pożyczki $\mathrm{u}$ holenderskich bankierów. Wydaje się, że czas na tego typu działania był jak najbardziej sprzyjajacy. Właśnie uchwalono Konstytucje Stanów Zjednoczonych i wzbudziła ona duże zainteresowanie w Europie, a w kręgach oświeconych, filozofów i encyklopedystów rozgorzała na jej temat interesujaca dyskusja. Thomas Jefferson, chociaż wygłosił szereg krytycznych uwag na temat Konstytucji, uważał jednak, że nowa ustawa podniesie nadwattlony prestiż Stanów Zjednoczonych na arenie międzynarodowej i w kręgach europejskiej finansjery. Spodziewał się, że ustabilizowanie sytuacji wewnętrznej kraju pomoże mu wyjść $z$ zapaści finansowej i odsunie terminy spłaty rządowych długów ${ }^{11}$.

John Adams, który był w tym czasie posłem Stanów Zjednoczonych w Anglii, patrzył bardziej sceptycznie w przyszłość i dlatego pragną jak najszybciej powrócić do Ameryki, aby aktywnie uczestniczyć w reformach kraju. Na początku marca 1788 r. powiadomił Thomasa Jeffersona, że zamierza opuścić Londyn i wyjechać do Republiki Zjednoczonych Prowincji w celu zlikwidowania swoich poprzednich starań kredytowych i obowiazków służbowych ${ }^{12}$. W zwiąku $z$ tym Jefferson natychmiast wysłał depeszę do Anglii proszacc swojego kolegę o spotkanie i przedłużenie pobytu w Holandii, dopóki on sam nie zdoła tam dojechać. Uważał, nie bez podstaw, że uchwalenie Konstytucji pomoże w zdobyciu zaufania holenderskich bankierów i odsunie groźbę bankructwa kraju13.

Thomas Jefferson opuścił Paryż 4 marca 1788 r. i w towarzystwie jednego lokaja podróżował prywatnym powozem korzystając po drodze $z$ zajazdów i tawern. Jechał $\mathrm{w}$ pośpiechu w kierunku

11 Więcej o poglądach Thomasa Jeffersona na temat amerykańskiej Konstytucji por. m.in. K. Ste $1 \mathrm{~m}$ a s ia k, Amerykańska konstytucja federalna $w$ opiniach Tomasza Jeffersona $z$ lat 1787-1789, [w:] Konstytucja Stanów Zjednoczonych. Reminiscencje $w 220$ rocznicę uchwalenia, red. J.A. Daszyńska, Łódź 2009, s. 307-317.

12 Por. Abigail Adams do Thomasa Jeffersona, 26 II 1788, The Papers of Thomas Jefferson..., vol. XII, s. 624; J. Grobis, op. cit., s. 118-120; Z. Libi is zowska, op. cit., s. 159-160; J.M. A11is o n, Adams and Jefferson: The Story of a Friendship, Norman 1966, s. 106-107.

13 Por. The Autobiography of Thomas Jefferson..., s. 93; Th. Jefferson do George'a Waszyngtona, 2 V 1788, The Papers of Thomas Jefferson..., vol. XIII, s. 126; G.G. S h a c k el f or d, Thomas Jefferson's Travels in Europe, 1784-1789, Baltimore-London 1995, s. 131; Z. Libiszowska, op. cit., s. 160. 
granicy $z$ austriackimi Niderlandami. $Z$ braku czasu nie podziwiał terenów, przez które przejeżdżał. Zatrzymywał się na krótko tylko po to, aby zmienić konie w zaprzęgu. Początkowo trasa podróży wiodła przez lesiste lub wyludnione tereny północno-wschodniej Francji - Pikardię. Pod drodze mijał Louvres, Senlis (Oise), Roye (Somme), a na noc zatrzymał się w Peronne.

Następnego dnia zrobił krótką przerwę na posiłek w Cambrai (Cambray), ale nie podziwiał okazałej gotyckiej katedry NotreDame, która wkrótce znacznie ucierpiała w czasie Rewolucji francuskiej, i nie wspomniał o prężnie działających wtedy manufakturach tego miasta. Granicę francuską przekroczył w Valenciennes i kontynuował podróż na północ. Na noc zatrzymał się w przydrożnej tawernie niedaleko Brukseli.

Trzeciego dnia podróży wstał wcześnie rano i do stolicy południowych Niderlandów dotarł w porze śniadania. Znowu nie miał czasu, aby podziwiać wspaniałości Brukseli, pomimo że John Adams polecał to miasto jako godne zobaczenia. Kolejnym etapem podróży było Mechelen. Postój w mieście podyktowany był koniecznościa zmiany koni. Ponownie nie było okazji do zwiedzania, chociaż miasto odgrywało istotna rolę polityczna i gospodarczą już od czasów późnego średniowiecza. Krótko przed wizytą Thomasa Jeffersona w Mechelen zostały zburzone na rozkaz Józefa II fortyfikacje miejskie (1781). Wieczorem dyplomata zdołał dotrzeć do Antwerpii zanim zamknięto jej bramy.

W drugiej połowie XVIII w. Antwerpia nie była już wspaniałym ośrodkiem handlu, a tylko podupadłym prowincjonalnym miastem. Co prawda pod austriackim panowaniem (1713-1794) Józef II próbował uwolnić rzekę Skaldę od holenderskiej blokady, ale jego plany nie zakończyły się sukcesem ${ }^{14}$. Rankiem 7 marca Thomas Jefferson wymienił $\mathrm{w}$ kantorze francuskie liwry na holenderskie floreny i przez chwilę mógł obserwować, jak flamandzcy bankierzy robia swoje interesy. Dyplomata nie obejrzal jednak największej atrakcji Antwerpii - słynnych obrazów Rubensa zgromadzonych w katedrze i w prywatnych zbiorach.

W dalszą podróż Thomas Jefferson ruszył powozem zaprzęgniętym nie w cztery, ale w sześć koni. Powodem zwiększenia siły zaprzęgu były piaszczyste drogi. Po przekroczeniu Skaldy dyplomata znalazł się na terytorium Zjednoczonych Prowincji. Podróżu-

14 Więcej o polityce Józefa II w południowych Niderlandach por. m.in. J. Ł a p t o s, op. cit., s. 114-123. 
jąc przez Północną Brabancję przejechał przez średniowieczne miasto Den Bosch, ale nawet jednym słowem nie wspomniał o słynnej katedrze św. Jana powszechnie uważanej za najlepszy przykład kościelnej architektury gotyckiej w północnych Niderlandach.

W sobote 8 marca Thomas Jefferson dotarł do Rotterdamu. Miasto tętniło życiem. W XVI stuleciu rozpoczęto tu budowę portu, który zdominował rozwój miasta. Poza przemysłem okrętowym i handlem, głównie $z$ Anglią i Francją, w Rotterdamie świetnie prosperował także przemysł sukienniczy. W wieku XVIII podróżni przybywajacy do miasta podziwiali m.in. pomnik słynnego Erazma (1467-1536) trzymającego książkę w dłoni. Szczęśliwym zbiegiem okoliczności Thomas Jefferson uczestniczył w Rotterdamie w obchodach czterdziestych urodzin księcia Wilhelma V Orańskiego, który urodził się 8 marca 1748 r. w Hadze. Huczne zabawy uliczne i wspaniała iluminacja świetlna towarzyszyła obchodom ku czci namiestnika, którego pozycja w państwie jeszcze kilka miesięcy wcześniej była poważnie zagrożona. Teraz pomarańczowe kokardy domu orańskiego wszędzie rzucały się w oczy.

Następnego dnia Thomas Jefferson w końcu zobaczył się z Johnem Adamsem w Hadze. Dyplomata nie krył radości $z$ tego spotkania. Tę część swej podróży podsumował w listach. Przez pierwsze dwa dni pokonał na tyle duży odcinek drogi, iż sądził, że uda mu się dotrzeć do Hagi trzeciego dnia w nocy. Niestety w kolejnych dniach nie jechał już tak szybko, w dodatku jeden dzień stracił oglądając uroczystości w Rotterdamie. Nie krył jednak zadowolenia $z$ tego powodu, ponieważ jego dość monotonna wyprawa została nieco urozmaicona. O krajobrazie pisał niewiele. Podkreślał rolniczy charakter kraju. Mijał pola, pastwiska i łąki podobne do tych, jakie znał w rodzinnej Wirginii. Nie zachwycał się urodą Krajów Nizin, tak jak czynili to członkowie rodziny Adamsów. Wydaje się, że nie do końca dostrzegał zalety położenia geograficznego tego regionu w centrum Europy, ukształtowania jego powierzchni i łatwości $\mathrm{w}$ poruszaniu się $\mathrm{w}$ terenie drogami lądowymi oraz kanałami15.

Z Hagi Thomas Jefferson i John Adams pojechali do Amsterdamu - ówczesnej stolicy światowej finansjery. Rozmowy na temat

15 Por. The Autobiography of Thomas Jefferson..., s. 94; Th. Jefferson do Williama Shorta, 10 III 1788 i Th. Jefferson do Johna Jaya, 13 III 1788, The Papers of Thomas Jefferson..., vol. XII, s. 659, 661, 667; E. D u m b a u 1d, op. cit., 112-113; G.G. S h a c k e 1 f o r d, op. cit., s. 132-133. 
kredytów prowadzone $z$ holenderskimi bankierami, którzy zawiedli się już na transakcjach kredytowych $z$ Amerykanami, nie należały do łatwych. W końcu udało się przełamać kryzys i John Adams, po podpisaniu 13 marca wstępnej umowy, wyjechał do Londynu, aby przygotować się do powrotu do domu. Dalsze negocjacje Thomas Jefferson prowadził już samodzielnie. Wkrótce zauważył, że większość bankierów, $z$ którymi rozmawiał, nie była tak apolityczna, jak dotąd sądził. Wielu $z$ nich doskonale orientowało się $\mathrm{w}$ sytuacji międzynarodowej, a część popierała ruch patriotów. W ciagu następnych dwóch tygodni dyplomacie udało się uzyskać pożyczkę w wysokości miliona florenów i dwa lata odroczenia wszelkich poprzednich spłat kredytów kupców holenderskich dla amerykańskiego handlu. Był to niewatpliwy sukces, który zagwarantował także bezpieczeństwo finansowe jemu samemu jako ministrowi pełnomocnemu Stanów Zjednoczonych w Paryżu, ponieważ wynegocjowana przez niego pożyczka miała pozostać w Europie i być przeznaczona na spłatę najpilniejszych zobowiązań zewnętrznych i działalność dyplomatyczną ${ }^{16}$.

W przerwie między negocjacjami Thomas Jefferson skorzystał z okazji i zwiedził Amsterdam. Położone nad rzeka Amstel miasto zrobiło na nim duże wrażenie. W wieku XVIII Amsterdam nadal odgrywał wiodacca rolę $\mathrm{w}$ europejskim handlu i w świecie finansjery. Prawdopodobnie podczas negocjacji dyplomata mógł zobaczyć giełdę, której praca wyglądała jak wielki spektakl. Żona Johna Adamsa wspominała, że na ogromnym placu przez dwie godziny tysiące mężczyzn sprzedawało niemal wszystkie dostępne artykuły i towary. Ludzki gwar porównywała do brzęczenia roju pszczół. $Z$ kolei sekretarz Thomasa Jeffersona, William Short (1759-1849) podkreślał, że bankierzy byli tak naprawdę ludźmi bardzo nudnymi, ponieważ ich działania sprowadzały się do nieprzerwanego uporu w zdobywaniu nowego kapitału ${ }^{17}$.

Podczas pobytu w Amsterdamie Thomas Jefferson mieszkał w hotelu położonym w samym sercu miasta, u zbiegu ulic Rusland

16 Por. The Autobiography of Thomas Jefferson..., s. 94; G. Ch in a r d, Thomas Jefferson. The Apostle of Americanism, Boston 1948, s. 191-192; N.E. C u n n i n g h a m jr., In Pursuit of Reason. The Life of Thomas Jefferson, Baton RougeLondon 1987, s. 119-121; E. D u m b a u 1d, op. cit., s. 114; Z. Lib is zow ska, op. cit., s. 160; M. K im b a 11, Jefferson: The Sense of Europe, 1784-1789, New York 1950, s. 213-214; D. M alo n e, Jefferson and the Rights of Man, Boston 1951, s. 191-192.

17 Por. G.G. Sh a ck elford, op. cit., s. 134. 
i Kloveniersburgwal. Stąd rozpoczynał piesze wycieczki po holenderskiej metropolii. Podczas spacerów dostrzegł i zanotował wiele interesujących szczegółów. Zwrócił m.in. uwagę na belki podtrzymujące ściany domów, które były ułożone nie poziomo i pionowo, ale na kształt rombu. Zainteresowały go okna, które otwierały się w taki sposób, że wpuszczając do wnętrza pomieszczenia światło, chroniły przed opadami deszczu. Wspomniał o latarniach umieszczanych nad bramami, oświetlających zarówno sień domu, jak i chodnik. Dyplomata zawsze interesował się urzadzeniami technicznymi. Dlatego podziwiał mosty zbudowane na amsterdamskich kanałach, które otwierały się dla przepływajacych statków w sposób obrotowy. Obejrzał także po raz pierwszy w życiu wiatrak pełniący funkcję młyna zbożowego. Opisał szlifiernię diamentów i mechanizm, który przenosił łodzie przez tamy. Zwiedził urządzenia portowe i stocznię. Poza tym odnotował szereg drobnych wynalazków, które ułatwiały Holendrom wykonywanie codziennych czynności, takich jak stół do szatkowania liści lub taczka ${ }^{18}$.

Tak jak miał w swoim zwyczaju podczas podróży, Thomas Jefferson dokonał także w Amsterdamie wielu zakupów. Dwie skrzynie zapełnione towarami zostały wysłane do Paryża. Wśród holenderskich nabytków znalazły się wyroby żelazne, porcelana, materiały piśmienne, kawa, herbata i czekolada. Część z tych artykułów objęta była zakazem handlu, dlatego zostały one do Francji przemycone ${ }^{19}$.

Podczas pobytu w Amsterdamie dyplomata wyjechał na wycieczkę do Haarlemu. Prawdopodobnie zauważył pola tulipanów rozciagające się pomiędzy Lejda i Haarlemem, chociaż nie wspomniał o nich $\mathrm{w}$ żadnej $\mathrm{z}$ relacji. Zaskakuje także brak informacji o uniwersytecie w Lejdzie czy o kościele św. Piotra, w którym modlili się przyszli Ojcowie Pielgrzymi zanim wypłynęli do Ameryki w 1620 r. Inni Amerykanie odwiedzający Lejdę w II połowie wieku XVIII zawsze wspominali o tych miejscach, tak blisko zwiąanych $z$ ich własna historia. Warto także podkreślić, że uniwersytet w Lejdzie był najstarsza uczelnia w Republice, cieszył się dobra reputacją, a wśród jego studentów było kilku Amerykanów, m.in. synowie Johna Adamsa20.

18 Por. Thomas Jefferson's European Travel Diaries..., s. 107-108.

19 Por. E. D u m b a u ld, op. cit., s. 115.

20 Por. D.R. Perry, John Adams and Abigail Adams, [w:] American Travel Writers..., s. 11-12. 
W pobliżu Haarlemu Thomas Jefferson podziwiał neoklasycystyczną posiadłość angielskiego polityka Henriego Hope’a (17001789). Był pod dużym wrażeniem niewielkiego pałacu. Nazwał go jednym $z$ najwspanialszych $w$ Europie i wykonał pośpiesznie jego szkic w notatniku ${ }^{21}$.

Dzięki pomyślnie zakończonym negocjacjom finansowym Thomas Jefferson mógł sobie pozwolić na dalszą podróż po Zjednoczonych Prowincjach i krajach niemieckich. Pisał, że chciał powrócić do Paryża inna, nieznana sobie drogą. Po dokładnym przeanalizowaniu kosztów opuścił Amsterdam z końcem marca 1788 r. i wyjechał do Utrechtu. Podróżował przez tereny dobrze zagospodarowane. Droga poprowadzona była na grobli chroniącej pola uprawne przed zalaniem. Część łąk i pastwisk znajdowała się poniżej poziomu wody. Gospodarstwa były zadbane i świadczyły o zamożności mieszkańców Republiki. Dyplomata zauważył jednak, że nie wykazywano większej dbałości o wiejska architekturę22.

W Utrechcie Thomas Jefferson obejrzał wspaniała gotycka katedrę $\mathrm{z}$ najwyższą wieżą kościelną $\mathrm{w}$ północnych Niderlandach. W tym czasie miasto nie podniosło się jeszcze $z$ chaosu wywołanego niedawnymi walkami między patriotami a partią oranżystów. Dlatego uniwersytet - jeden $z$ najstarszych w Republice - wciąż był zamknięty.

Następnego dnia dyplomata ruszył w dalszą drogę. W relacjach napisał, że ziemia między Utrechtem a granica $z$ Niemcami była piaszczysta i nie nadawała się do uprawy wysokiej jakości pszenicy. W krajobrazie dominowały pola, wiejskie domy i kuchenne ogrody, starannie ogrodzone murami $z$ cegieł i żywopłotami chroniącymi przed silnymi wiatrami. Nie było lasu, jedynie sady - najczęściej $z$ jabłoniami.

Część podróży do Nijmegen Jefferson odbył statkiem płynącym po Renie. Pisał, że najlepsze miejsce do obserwacji znajdowało się na górnym pokładzie, gdzie podróżowali gentelmani, podczas gdy na dolnym siedzieli pijani farmerzy.

Nijmegen było ostatnim miastem w Zjednoczonych Prowincjach, które odwiedził dyplomata. Przez całe wieki była to graniczna forteca chroniąca północne Niderlandy przed niemieckimi najazdami. Ogromny kompleks umocnień dominował nad miastem do

21 Por. Thomas Jefferson's European Travel Diaries..., s. 110.

22 Por. Th. Jefferson do W. Shorta, 29 III 1788, The Papers of Thomas Jefferson..., vol. XII, s. 697. 
roku 1769, kiedy to został zburzony, a kamienie użyte do jego konstrukcji sprzedane jako materiał budowlany. Thomas Jefferson wspomniał o długiej historii miasta i $z$ pewnym niedowierzaniem odnotował, że miejsce, które wybrał na nocleg, gościło także Juliusza Cezara (100?-44 p.n.e.).

Dyplomata podziwiał położenie miasta. Wspiął się nawet na pobliskie wzgórza, aby obejrzeć stąd Ren. Pisał, że rzeka była w tym miejscu wystarczająco szeroka dla żeglugi wielu statków. Dyplomata zaobserwował nawet załadunek i rozładunek barek oraz sporządził szkic specjalnej platformy ułatwiającej pracę $\mathrm{w}$ porcie rzecznym ${ }^{23}$.

Jak zauważył Thomas Jefferson w Nijmegen, należało dostatecznie dobrze przygotować się do dalszej drogi, ponieważ warunki podróżowania po niemieckiej stronie były zdecydowanie gorsze. Opuszczajacc Zjednoczone Prowincje Thomas Jefferson był zaszokowany zmiana. Krajobraz i klimat były podobne, ale kraj wydał mu się ubogi i zaniedbany. Przyczyn tego stanu rzeczy dopatrywał się w sferze społeczno-ustrojowej. Sądził, że republikańskie rządy w Zjednoczonych Prowincjach zapewniały obywatelom powodzenie i dostatek, podczas gdy niemiecki despotyzm prowadził do biedy. Dyplomata snuł refleksje nad niszczycielskim charakterem władzy absolutnej. Uważał, że nawet we Francji reżim monarchy nie doprowadził do tak złych wyników, jak w Niemczech rządzonych przez wielu małych despotów. Był głęboko przekonany, że władza sprawowana przez monarchów posiadających nieograniczone, dziedziczne przywileje prowadzić może jedynie do zepsucia i upadku. Dalsza podróż utwierdziła go w tych poglądach, a jego krytyczny stosunek do własnej Konstytucji znacznie złagodniał24.

$\mathrm{Na}$ zakończenie rozważań o pobycie Thomasa Jeffersona w Zjednoczonych Prowincjach warto wspomnieć o jego stosunku do zastałej w kraju sytuacji politycznej. Dyplomata bardzo dobrze znał wydarzenia ostatnich kilku lat. W listach do amerykańskich przyjaciół dokładnie opisywał złożoność ruchów ludowych. Wiedział, że wśród patriotów istniał wyraźny podział na nurt arystokratyczny i demokratów. Jego zdaniem ci pierwsi dążyli do utrzymania władzy regentów w niezmienionej formie, ale w razie potrzeby bardziej byli skłonni iść na kompromis $z$ namiestnikiem niż dopuścić do władzy masy ludowe. $Z$ kolei demokraci mogliby posłuchać głosu

23 Por. Thomas Jefferson's European Travel Diaries..., s. 111-112.

24 Por. ibidem, s. 113; Z. L i b i s z ow s k a, op. cit., s. 161-162. 
ludu, ale brakło im odwagi. Dlatego zwolennicy namiestnika urośli $\mathrm{w}$ siłę, a patrioci zwlekali $\mathrm{z}$ odwołaniem członków rządu wtedy, kiedy mieli największe poparcie. Po latach w Autobiografii Thomas Jefferson wspominał, że celem patriotów było ustanowienie republikańskiego rządu. Ruch ten zdobył większość w Stanach Generalnych, ale przegrał, ponieważ namiestnik i jego zwolennicy odwołali się bezpośrednio do ludu. Tłum w Hadze sprzeciwił się członkom Stanów Generalnych. Byli oni atakowani i znieważani na ulicach miasta. $Z$ kolei namiestnik, którego zadaniem było powstrzymanie motłochu przed atakiem nienawiści i ukaranie zbuntowanych, nic w tej sprawie nie uczynił.

W listach dyplomata donosił, że walczace ze sobą ugrupowania posuwały się do licznych aktów przemocy. Dlatego przewidywał obca interwencję. Pisał, że zachłanni sąsiedzi $z$ uwaga obserwowali niepokój w Republice po to, aby w odpowiednim momencie powstrzymać demokratyczne siły. Uważał, że namiestnik prosząc o wstawiennictwo w Londynie i Berlinie zapomniał, że był pierwszym sługa w Republice. W Autobiografii wyjaśnił także szczegółowo okoliczności pruskiej interwencji w $1787 \mathrm{r}$.

Wydaje się, że Thomas Jefferson dość nieufnie patrzył na radykalizację życia publicznego w Republice. Uważał, że holenderskie wydarzenia powinny być lekcją dla Amerykanów, ponieważ mieszkańcy Zjednoczonych Prowincji nie uwolnili się od złych rządów pomimo ruchów ludowych. Pozwolili na ingerencję sąsiedniego kraju i dopuścili do wprowadzenia zasady dziedziczenia najwyższego urzędu w państwie. Wyrazili także zgodę na gwarancję tego stanu rzeczy przez obce mocarstwa. Dlatego dla Thomasa Jeffersona, tak bardzo ceniącego wolność i demokrację, widok Republiki, w której zgromadzenie przedstawicieli narodu zostało zdominowane przez dziedziczny urząd namiestnika, był przygnębiający. Dyplomata ze smutkiem obserwował, jak patrioci emigrowali do Francji, przygnębieni myślą o porzuceniu własnych ideałów. Wierzył jednak, że w niedalekiej przyszłości Francja zdecyduje się na zbrojna interwencje po to, aby odbudować wpływy patriotów w Republice i poniżyć raz jeszcze swoją odwieczną rywalkę - Anglię ${ }^{25}$.

25 Por. The Autobiography of Thomas Jefferson..., s. 84-85; Th. Jefferson do Edmunda Randolpha, 3 VIII 1787, The Papers of Thomas Jefferson..., vol. XI, s. 672673; Th. Jefferson do J. Jaya, 6 VIII 1787, ibidem, s. 693-700; Th. Jefferson do Johna Sullivana, 5 X 1787, ibidem, vol. XII, s. 209; J.W. S c h u 1 t e N o r d h o 1 t, The Dutch Republic and American Independence, London 1982, s. 275. 